N.P.K. is an M.R.C. research assistant. D.G.F.H. is in receipt of grants from the Muscular Dystrophy Group of Great Britain and also from the M.R.C. F.R.E. has received financial support from I.C.I. (Pharmaceuticals) Ltd. D.G.F.H and F.R.E have received financial support from the board of governors of Leeds General Infirmary.

\section{References}

Britt, B. A., and Kalow, W. (1970). Canadian Anaesthetists' Society fournal 17, 293.
Denborough, M. A., Forster, J. F. A., Lovell, R. R. H., Maplestone, P. A. and Villers, J. D. (1962). British fournal of Anaesthesia, 34, 395 Ellis, F. R., Harriman, D. G. F., Keaney, N. P., Kyei-Mensah, K., and Tyrrell, J. H. (1971). British fournal of Anaesthesia, 43, 721.

Griffiths, P. D. (1966). Clinica Chimica Acta, 13, 413.

Harriman, D. G. F. (1961). In Electrodiagnosis and Electromyography, ed. S. Licht, p. 134. New Haven, Connecticut, Burns and MacEachern. Isaacs, H., and Barlow, M. B. (1970). British Medical fournal, 1, 275.

Keaney, N. P., and Ellis, F. R. (1971). British Medical fournal, 4, 49.

King, J. O., Denborough, M. A., and Zapf, P. W. (1972). Lancet, 1, 365.

Larard, D. G., Rice, C. P., Robinson, R., Spencer, R. W., and Westhead R. A. (1972). British fournal of Angesthesia, 44, 93 .

Parikh, R. K., and Thomson, W. H. S. (1972). British fournal of Anaesthesia In press.

Steers, A. J. W., Tallack, J. A., and Thompson, D. E. A. (1970). British Medical fournal, 2, 341 .

\title{
Circadian Periodicity of Serum Prolactin Concentration in Man
}

\section{J. NOKIN, M. VEKEMANS, M. L'HERMITE， C. ROBYN}

British Medical fournal, 1972, 3, 561-562

\section{Summary}

Immunoreactive human serum prolactin of pituitary origin has been measured by a radioimmunoassay developed for ovine prolactin. Blood samples were collected at four-hour intervals during a 24-hour period from 12 non-pregnant women, three pregnant women, and seven adult men. A circadian periodicity was found in serum prolactin concentration, with peak values during the night, between 1 a.m. and 5 a.m. for the nonpregnant women, and at $5 \mathrm{a.m}$. for the adult men. Mean serum levels of prolactin were 1.5 times higher in nonpregnant women than in men. In women investigated during the last month of their pregnancy the mean serum prolactin levels were 2.3 times higher than in the non-pregnant women, but there was no circadian periodicity.

\section{Introduction}

A circadian periodicity in serum prolactin concentration has been found in rats (Clark and Baker, 1964; Dunn et al., 1972). The purpose of the present study was to investigate whether a similar rhythm exists in man.

\section{Subjects and Methods}

Blood samples were collected at four-hour intervals during 24 hours from 22 normal adult volunteers-12 non-pregnant women aged 19-44 years, 7 men aged 23-64 years, and 3 pregnant women aged 27-33 years who were investigated during the last month of their pregnancy. Among the non-pregnant women two were in the follicular phase and 10 were in the luteal phase of their menstrual cycle.

Human prolactin was measured in serum using a radioimmunoassay method initially developed for ovine prolactin (Davis et al., 1971) and extended to human prolactin (L'Hermite et al., 1972a; Midgley et al., 1972). Highly purified ovine prolactin (LER-860-2) was labelled with ${ }^{125}$ I (Radiochemical Centre, Amersham, England) at a dose of $1 \mathrm{mCi} / 2.5 \mu \mathrm{g}$, using

Human Reproduction Research Unit, Hôpital Saint Pierre, University of Brussels, Belgium

J. NOKIN, M.D., Postdoctoral Fellow

M. VEKEMANS, M.D., Resident

M. L'HERMITE, M.D., Resident

C. ROBYN, M.D., Research Worker, Fonds National de la Recherche Scientifique the chloramine-T method (Greenwood et al., 1963). The labelled prolactin was separated from free iodide by chromatography on Sephadex G-100 (Pharmacia, Uppsala, Sweden) equilibrated with $0.05 \mathrm{M}$ phosphate buffer at $\mathrm{pH} 7 \cdot 0$. Thereafter the fractions of the ${ }^{125}$ I-prolactin peak were diluted with phosphate buffer in saline containing $1 \%$ egg white (Sigma Chemical Co., St. Louis, Mo.) in order to obtain a working solution containing 50,000 c.p.m./100 $\mu$ l. The assays were conducted according to the double antibody method using $200 \mu \mathrm{l}$ of sample or standard with $200 \mu \mathrm{l}$ of antiovine prolactin serum 770 at a dilution of $1: 72,000$ in normal rabbit serum diluted at 1:600 in phospliate-buffered saline (pH 7.0) containing $0.05 \mathrm{M}$ ethylenediaminetetra-acetic acid (EDTA), $300 \mu$ of phosphate buffer in saline containing $1 \%$ egg white, $100 \mu \mathrm{l}$ of radioactive tracer solution, and $200 \mu \mathrm{l}$ of sheep antirabbit immunoglobulins serum at a dilution of $1: 100$ in phosphate-buffered saline containing 0.05 M EDTA.

Non-equilibrium conditions were employed as described previously (L'Hermite and Midgley, 1971). No cross-reaction was detected in this system with human growth hormone and with human chorionic somatomammotrophin (L'Hermite et al.s 1972b; Midgley et al., 1972). All assays were conducted with reference to pooled sera collected from pregnant women. We conferred an immunological activity of $1.0 \mathrm{mU}$ on the amount of prolactin contained in $1.0 \mu \mathrm{l}$ of this pool used as laboratory standard. All samples from the same subject were run in triplicate in the same assay. The assay results were calculated according to the recommendations of Rodbard et al. (1968).

\section{Results}

The mean serum prolactin levels observed over the 24-hour period are shown in the Chart for men and non-pregnant women, and in the Table for pregnant women. The data were submitted to a variance analysis (Snedecor, 1956) of the between-subjects variation and the within-subject variation due to the influence of time. There was a highly significant variation between the subjects in serum levels of prolactin-non-pregnant women $\mathrm{F}=8.27, \mathrm{P}<0.001$; adult men $\mathrm{F}=3.81, \mathrm{P}<0.001$; pregnant women $F=8.09, P<0.01$. In addition in the non-pregnant women the levels of prolactin were higher $(F=68.99$; $P$ $<0.001$ ) at 1 a.m. (mean $500 \mathrm{mU} / \mathrm{ml}$ ) and 5 a.m. $(504 \mathrm{mU} / \mathrm{ml}$ ) than at 9 a.m. (332 and $312 \mathrm{mU} / \mathrm{ml})$, 1 p.m. $(273 \mathrm{mU} / \mathrm{ml}), 5$ p.m. $(299 \mathrm{mU} / \mathrm{ml})$, and 9 p.m. (331 mU/ml). There was no significant difference in serum levels of prolactin found at 9 a.m. between the first and the second day $(F=0.24 ; P>0.05)$. The prolactin levels started to increase at 9 p.m., but this rise was not significant $(F=1.76 ; P>0.05)$ compared with the values seen at 1 p.m. and 5 p.m.

In the men there was also a peak in serum prolactin levels 


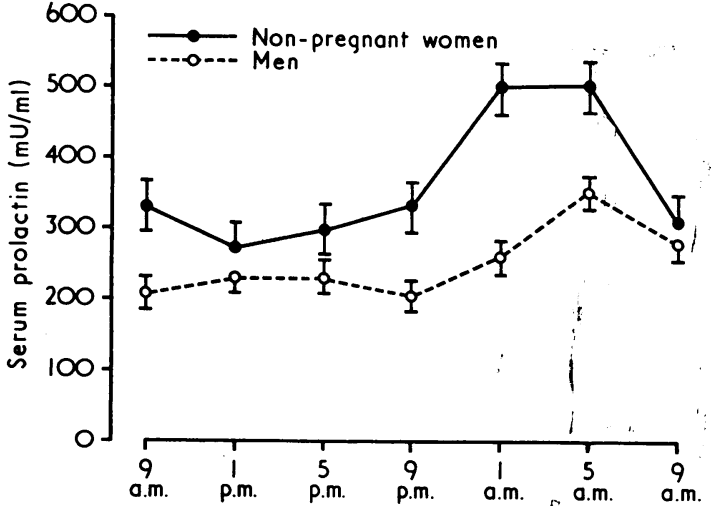

Mean immunoreactive serum prolactin levels in blood samples collected at 4-hour intervals during a 24-hour period from 12 non-pregnant women and 7 men. The common standard errors of the means calculated by variance analysis are shown.

Immunoreactive Human Serum Prolactin (in mU/ml) assayed in Blood Samples collected at various Times during 24-hour Period from Three Women during the Last Month of Pregnancy

\begin{tabular}{c|c|c|c|c|c|c|c}
\hline $\begin{array}{c}\text { Case } \\
\text { No. }\end{array}$ & 9 a.m. & 1 p.m. & 5 p.m. & 9 p.m. & 1 a.m. & 5 a.m. & 9 a.m. \\
\hline 1 & 911 & 824 & 947 & 725 & 787 & 708 & 774 \\
2 & 817 & 863 & 743 & 739 & 765 & 687 & 825 \\
3 & 953 & 773 & 1,261 & 1,189 & 953 & 937 & 1,031 \\
\hline Mean $^{*}$ & 894 & 820 & 984 & 884 & 835 & 777 & 877 \\
\hline
\end{tabular}

* Common standard deviation calculated by variance analysis $=119 \mathrm{mU} / \mathrm{ml}$.

during the night but it was of less amplitude. The mean levels at 1 a.m. (270 mU/ml) and 5 a.m. ( $354 \mathrm{mU} / \mathrm{ml}$ ) were higher $(\mathrm{F}=17.03 ; \mathrm{P}<0.001)$ than those at 9 a.m. (209 and 280 $\mathrm{mU} / \mathrm{ml}), 1$ p.m. $(222 \mathrm{mU} / \mathrm{ml}), 5$ p.m. $(222 \mathrm{mU} / \mathrm{ml})$, and 9 p.m. $(205 \mathrm{mU} / \mathrm{ml})$. The mean prolactin level at 9 a.m. was significantly higher the second day than the first day $(F=4.74 ; \mathrm{P}<0.05)$; also the value at 5 a.m. was higher than that at 1 a.m. $(F=$ $8.37 ; \mathrm{P}<0.01)$. Mean serum prolactin levels during the period of observation were higher $(F=19.09 ; \mathrm{P}<0.001)$ in non-pregnant women $(364 \mathrm{mU} / \mathrm{ml})$ than in men $(250 \mathrm{mU} / \mathrm{ml})$. Mean levels were also slightly higher during the luteal phase $(372 \mathrm{mU} / \mathrm{ml})$ than during the follicular phase $(323 \mathrm{mU} / \mathrm{ml})$, but this difference was not statistically significant $(F=2.06 ; P>0.05)$.

Finally, as indicated in the Table, no circadian periodicity could be found in the three pregnant women investigated during the last month of their pregnancy.

The values at 1 a.m. $(835 \mathrm{mU} / \mathrm{ml})$ and 5 a.m. $(777 \mathrm{mU} / \mathrm{ml})$ were slightly lower than those at 9 a.m. (894 and $877 \mathrm{mU} / \mathrm{m}$ ), 5 p.m. $(984 \mathrm{mU} / \mathrm{ml})$, and 9 p.m. $(884 \mathrm{mU} / \mathrm{ml})$. This difference, however, was not statistically significant $(F=3.01 ; P>0.05)$. The mean serum prolactin levels during the period of observation were higher $(F=96.8 ; P<0.001)$ in pregnant women (867 $\mathrm{mU} / \mathrm{ml})$ than in non-pregnant women $(364 \mathrm{mU} / \mathrm{ml})$.

\section{Discussion}

Immunoreactive serum prolactin, as measured by the radioimmunoassay method used here, has been found to be raised in lactating women where, in addition, peak values have occurred in response to breast-feeding (L'Hermite et al., 1972c), in cases of various types of galactorrhoea, and during treatment with psychotropic drugs such as chlorpromazine and sulpiride (L'Hermite et al., 1972a). From the data obtained recently with the same assay method serum levels of prolactin increase also during pregnancy (L'Hermite et al., 1972c), after intravenous injection of thyrotrophin releasing hormone (L'Hermite et al., 1972b), and in response to insulin-induced hypoglycaemia (L'Hermite et al., 1972a, 1972d). Peak values of serum prolactin were found during the night between 1 a.m. and 5 a.m. both in men and in non-pregnant women. A release of prolactin from the pituitary, occurring with a circadian periodicity, was most likely responsible for this rhythmic fluctuation of serum levels. The mechanism of control could be either a transitory suppression of the prolactin inhibiting factor (Sulman, 1970a) or an increased secretion of a prolactin releasing hormone (Sulman, 1970b).

Synthetic thyrotrophin releasing hormone-that is, (pyro)GLU-HIS-PRO $\left(\mathrm{NH}_{2}\right)$-induces not only a release of thyrotrophin but also a release of prolactin (Bowers et al., 1971; Jacobs et al., 1971; L'Hermite et al., 1972b). Moreover, circadian periodicity exists also in serum levels of thyrotrophin-indeed, as for prolactin, peak values of serum thyrotrophin occurred during the night around 5 a.m. (Vanhaelst et al., 1972). Further studies are required to elucidate whether the release of both thyrotrophin and prolactin, occurring with a circadian periodicity, would be associated in time and therefore possibly controlled by the same hypothalamic releasing hormone. Owing to the existence of a circadian periodicity in prolactin secretion variations of the serum levels of this hormone occurring in physiopathological and experimental conditions cannot be based entirely on single samples collected during the day. A more precise evaluation of prolactin secretion should be based on frequent blood sampling during the day and night or possibly on evaluation of the total output in 24-hour urine collections. The fact that lactotrophic activity has been found by biological methods in urinary extracts (von Berswordt et al., 1967) favours this last solution.

The disappearance of the circadian periodicity in serum prolactin concentration during pregnancy has to be confirmed by increasing the number of cases studied. It would also be of interest to investigate at what age of pregnancy this periodicity is lost and when it appears again after delivery.

We thank Mrs. A. Guttermann, Miss J. Desnoeck, Miss M. Morsa, and Mr. A. Van Meenen for technical help. We are indebted to Dr. G. D. Niswender for a generous gift of the ovine reagents used for prolactin assay. This work was supported by research and training grants from the Ford Foundation and from the "Fonds de la Recherche Scientifique Médicale de Belgique" to Professor P. O. Hubinont, and from the "Fondation LekimeRopsy."

Requests for reprints should be addressed to C. Robyn, Department of Gynaecology and Obstetrics, Hôpital Saint Pierre, 322, rue Haute, 1000 Brussels, Belgium.

\section{References}

Bowers, C. Y., Friesen, H. G., Hwang, P., Guyda, H. J., and Folkers, K. (1971). Biochemical and Biophysical Research Communications, 45, 1033. Clark, R. H., and Baker, B. L. (1964). Science, 143, 375.

Davis, S. L., Reichert, L. E., and Niswender, G. D. (1971). Biology of Reproduction, 4, 145 .

Dunn, J. D., Arimura, A., and Scheving, L. E. (1972). Endocrinology, 90, 29. Greenwood, F. C., Hunter, W. M., and Glover, J. S. (1963). Biochemical Fournal, 89, 114.

Jacobs, L. S., Snyder, P. J., Wilber, J. F., Utiger, R. D., and Daughaday, W. (i971). Journal of Clinical Endocrinology and Metabolism, 33,966.

L'Hermite, M., and Midgley, A. R. (1971). Fournal of Clinical Endocrinology and Metabolism, 33, 68

L'Hermite, M., Delvoye, P., Nokin, J., Vekemans, M., and Robyn, C. (1972a). In Tenovus Workshop on Prolactin and Carcinogenesis, ed. K. Griffiths and A. R. Boyns, Cardiff, Tenovus Organization. In press. L'Hermite, M., et al. (1972b). Lancet, 1, 763.

L'Hermite, M., Stavric, V., and Robyn, C. (1972c). Acta Endocrinologica, 69, Suppl. No. 159, p. 37. L'Hermite, M., et al. (1972d). Fourth International Congress of EndoMidgley, A. R., L'Hermite, M., and Jaffe, R. B. (1972). Unpublished.

Rodbard, D., Rayford, P. L., Cooper, J. A., and Ross, G. T. (1968). Fournal of Clinical Endocrinology and Metabolism, 28, 1412.

Snedecor, G. W. (1956). Statistical Methods applied to Experiments in Agriculture and Biology, 5th edn., p. 291. Ames, Iowa, U.S.A., Iown Agriculture and Biology,

Sulman, F. G. (1970a). Hypothalamic Control of Lactation, p. 7. Berlin, Springer.

Sulman, F. G. (1970b). Hypothalamic Control of Lactation, p. 13. Berlin, Springer.

Vanhaelst, L., Van Cauter, E., De Gaute, J. P., and Golstein, J. (1972) Fourth International Congress of Endocrinology, $W$ ashington. Amsterdam Excerpta Medica. I.C.S. 256, p. 184

von Berswordt-Wallrabe, I., Flaskamp, D., and Jantzen, K. (1967). Acto Endocrinologica, 56, Suppl. No. 119, p. 126. 